\title{
Conditional Liberation - One of the Measures to Achieve the Purpose of Criminal Punishment
}

\author{
Nicoleta-Elena Hegheș ${ }^{1}$, Victoria Cristiean ${ }^{2}$ \\ “Dimitrie Cantemir” Christian University of Bucharest, Romania,nicoleta.heghes@ucdc.ro \\ “Dimitrie Cantemir” Christian University of Bucharest, Romania, victoria.cristiean@gmail.com
}

\begin{abstract}
The offense as a fact forbidden by the rules of criminal law cannot exist without the unavoidable consequence of criminal liability, which, in its turn, would be without object without a criminal sanction, without a punishment. Neither punishment can be conceived without the existence of criminal liability and it is based only on the offense. Conditional liberation constitutes a measure of both criminal and social policy that is particularly important for achieving the purpose of punishment. Conditional liberation is conceived as an incentive for convicts who give evidence of correction by reducing the period of deprivation of liberty, being designed to accelerate the process of re-education and social reinsertion of the convict.
\end{abstract}

KEYWORDS: conditional liberation, convicts, measures, punishment, recidivists

\section{Introduction}

The conditional liberation was introduced for the first time in Romanian Criminal Law in 1874, only for juveniles, and later through the Penitentiary Law of July 30, 1929, it was generalized in the sense that it was possible for all convicts of deprivation of liberty. In 1934, the Legislative Council revised and completed the draft Criminal Code of 1928 and 1933, which were the basis for the promulgation of the High Royal Decree no 471/03.17.1936. Initially, conditional liberation was granted only to those who have been sentenced to temporary sentences, those sentenced to life imprisonment being excluded from the benefit of this institution. Likewise, no recidivist convicts could benefit from conditional liberation (Bălășescu 2015, 22). The limitations of conditional liberation were criticized at that time, and it was established that nothing would dare to suppose that a convicted person would not change his behavior, showing good conduct before the full deprivation of freedom to which he was condemned. The same applies when we talk about recidivists, including a recidivists of the occasion(Tanoviceanu, 1927, 423424). However, who is responsible for the crimes of non recurrent recidivists who take advantage of the law clemency? These two limitations have not found their place in the Criminal Code since 1936 or later. According to article 153 point 2 of the Law on the organization of penitentiaries and prevention institutions of July 30, 1929, convicts could get conditional release if they met several conditions, among which:

- convicts of criminal punishment have executed at least half of the sentence;

- those sentenced to correctional punishment to have executed at least one-third of the sentence, but not less than 6 months (Bălășescu 2015, 23-24). The Criminal Code adopted on June 21, 1968 and entered into force on January 1, 1969 distinguishes between the granting of conditional liberation, between offenses against State security, against public order or the offense of murder, or crimes against peace and mankind, or crimes against which produced a significant damage to the national economy and other crimes, the penalty fractions to be executed being higher for the former (see article 60 of the Criminal Code 1968).

\section{Conditional Liberation - notion and practical aspects}

Conditional liberation is one of the ways of judicially individualizing the execution of punishment consisting in the release of the convict from the place of detention before fully executing the custodial sentence at which he was convicted, namely life imprisonment or imprisonment, with respect for certain terms. Thus, the person of the convict, regardless of the nature of the offense committed and the manner of committing it, with or without violence, if he fulfilled the conditions provided by article 99 and article 100 of the Criminal Code, he may be released conditionally.

Although in the literature it is stated that this institution has an optional character, not representing a right, but only a general vocation of the convict (Udroiu 2014, 184), the practice 
shows that it does not apply as an exception but as a generality, constituting in a way or another right of the convict, who fulfills the conditions sine qua non provided by law, will be compulsorily released conditionally.

From the definition given to punishment, namely a penalty of criminal law, which is a measure of coercion and re-education, established by the law and which applies to the offender by the court, in order to prevent the commission of new crimes (Pascu, Uzlău 2013, 341), it is without doubt its purpose, preventing the commission of new offenses.

By preventing the commission of new offenses is meant the prevention of the commission of new offenses on the part of the person who has been subjected to a punishment, the special prevention, which will be accomplished through the totality of the activities to which the convict is subjected during the execution of the punishment and the prevention of committing crimes the part of any other person, general prevention, which is largely achieved by the resonance of a conviction to a punishment (Antoniu 1998, 19).

The problem arises when this conditional release no longer contributes to the purpose of punishment, but instead creates the legal framework for action by certain criminals. In support of this assertion, we will come up with several arguments throughout this paper.

Although, apparently, in its functionality the penitentiary cannot be contemporary with the social moment, the prison system can progress. The evolution of an institution is determined by the emergence and promotion of new organizational needs, cultural needs, the need for identity, the existence of mechanisms for preventing and fighting crises (Gheorghe 2005,196). Thus, it is imperative that all the state institutions involved in this process that we speak of are held accountable, and those who deviate from the legal norms to respond according to the positive law. A particularly important role is to prevent it (Prevention is the set of measures addressing the factors that determine or favor the occurrence of socially dangerous facts with the aim of restraining and annihilating the harmful effects thereof - Gheorghe 2005, 175), in order to prevent a person from committing an offense. And if it has been done, and this is not a single one, but it becomes more or less a social phenomenon, to take preventive measures, including by modifying the legal provisions.

Conditional liberation, either from life imprisonment or imprisonment, is conceived as a stimulant for convicts. It is based on the premise that convicts, including criminals, may be wronged, and this is ultimately the purpose of punishment. According to the law, once the convicted persons are admitted to the penitentiary, the necessary activities are carried out for their release. Each penitentiary unit itself is organized as a society, namely convicts can work, volunteer, participate in various courses, can be visited, enjoy daily walk, receive and buy various goods, support family members and others, is certain that certain restrictions of movement, freedom, according to the execution regime of the person, must be respected, which is very normal, since we are still talking about an offender (Because, as a prototype of the totalitarian institution, the penitentiary shelters thousands of criminals for a certain period of time, who must serve their punishment contrary to their will. All soul infirmities go to the surface when shame disappears when they have nothing to risk, feeling alone and abandoned by the family. At that time, there is a need for compensations that make condemned men to be hard to imagine. "When destructive violence occurs, it translates the confusion, the absence of perspective, sentimental to being caught in a trap, without the hope of leaving" - see Boiangiu in "Dilema" no 346).

Corollary to the said, from an isolated institution of society, the penitentiary must be a meeting place for community interests, social policies in criminal matters, a source of ideas for effective social interventions (Gheorghe 2005, 196).

In the following we present a case study:

The first serial killer of Brăila, F.M., has three murders, three rapes, robberies, imprisonment and attempted murders. He killed three people with cold blood in 1992 and then a third person. The victims were two women and a man, unobtrusive, octagonal. He raped the victims, and because they resisted, he killed them. He was released conditionally by the court in 2013 at the proposal of the Brăila Penitentiary Commission, considering that the time has come for him to reintegrate into 
society. But it turned out that he does not deserve this leniency from the judge and the legislator, he killing again (Antonescu 2017).

Most likely, the cold-blooded recidivist in the detention period was diligent in work, disciplined, gave good evidence of straightening, and convinced the committee that he deserved to be released to reintegrate into society. However, it seems that the problem of sexuality has not been solved, not even improved. These offenses arose precisely because he was trying to have sexual relation with these people, but he was rejected, and by not controlling his sexual instincts and motions, raping the victims and killing them. The victims were part of a certain category: those who could not defend themselves, the elderly, those living alone. The relatives, as well as the policemen who oversaw it, hoped that he had finally escaped the sick obsession of violating and killing elders. What will happen if he is conditioned liberation and will again relapse?

\section{De Lege Ferenda proposals}

It cannot be denied that the law, especially the criminal law which, as the famous European Court of Human Rights says, assumes the role of "guard dog" of the social order (see C.E.D.O., Decision Observ and Guardian v. Great Britain, dated 26.11.1991, 59), and its purpose is to defend the fundamental values of life in society, must also prevent and resolve, through its provisions, all the practicalities, the problems facing society, especially when in the middle is the right to life.

In another train of thoughts, the general prevention of the commission of new offenses is accomplished by establishing in law acts that constitute offenses, the members of the society being aware of the consequences of committing such acts, as well as of the legal limits of sanctioning them. We believe that through a correct, rigorous and comprehensive regulation of the conditions of granting conditional release, the general prevention of the above speech will be ensured.

At present, the Criminal Lawmaker states the conditions for the granting of conditional liberation in the case of life imprisonment in article 99 para. 1 of the Criminal Code, and the conditions of conditional release in the case of imprisonment in article 100 para. 1 of the same normative act. The conditions for the granting of conditional liberation in the case of life imprisonment and imprisonment are similar except for the fraction or duration of punishment actually to be executed and the condition that the sentenced person to be found in the execution of the sentence in a semi-open or open sentence in case of imprisonment.

We believe that these conditions must be exacerbated when the subject of conditional release is a criminal, who committed the deed through violent means, which violate the most important social values and which denotes a high degree of danger, but also a life style of the offender. Also, when referring to criminals of serious crimes such as murder, qualified murder, rape, out of the considerations presented, they should not benefit from this leniency.

What happens if a convicted person for serious crimes that interfere with the most important social values of man by means that attract the abhorrence of others and who have certain sexual "deviations", for example, released conditionally, relapses? It is moral, normal for the legislator to create the legal framework by which, after being imprisoned again, to be conditional liberation?

We believe that it is imperative to amend the legal provisions governing the institution of conditional liberation in relation to offenders committing particularly grave crime, by ways, means that attract abhorrence of those who know of these facts (murder, qualified murder) and which reflects a style of life, and the offenses are not committed by momentary impulses. Concretely, these criminals cannot benefit from the provisions of this institution, precisely because of the need for the purpose of punishment to be achieved and no more cases of recidivism.

With reference to article 100 of the present Criminal Code, which sets out the conditions of conditional liberation in the case of imprisonment, among which is that the sentenced person is in the execution of the penalty in a semi-open or open regime (Toader 2017, 55), we have the opinion that the offense and the means of committing it. Since, according to the Decision no. 157/2016 approving the Regulation implementing Law 254/2013 on the execution of sentences and detention measures, establishes that the semi-open regime can also be applied to detainees initially classified 
under the closed regime but who have had good conduct and have made diligent efforts for social reintegration (article 74, para. (2), let. c), Romanian Criminal Code).

\section{Psychological aspects}

From the point of view of personality, some psychologists believe that human is a being eminently oriented towards hedonism, so he does not avoid the facts that ultimately cause him the greatest inconvenience. This was explained by American psychologist O.H. Mawrer in that when an action has two consequences, one positive and another negative, of sanction, both consequences being equal in weight, then the conflict is solved according to the closest possible consequence in time. In the case of an offense, the immediate consequence is the positive one, that is, the one that offers immediate moral or material satisfaction, as long as the legal sanction is more remote and compared to the recidivist with a degree of uncertainty (Butoi and Butoi 2004, 61-62).

In a paper in 1955, Harold Linder tells us that criminal situation occurs when predisposing motivations are "ignited" by the circumstantial environmental factors, and under such conditions, criminal behavior is an attempt of the individual to relax by resolving internal tension and restoring the initial balance, as we have seen in the case presented above. (Butoi and Butoi 2004, 64).

Recidivists are individuals for whom crime is a way of life, and they are more dangerous. With certain personality traits, such as intellectual immaturity, increased impulsivity, aggressiveness, emotional indifference, egocentrism, opposition tendency, skepticism, low resistance to stimuli, they start criminal activity through facts that do not present a high degree of danger (Ibidem, 68), exempli gratia theft and culminating with some particularly serious crimes: robberies and murders

The court cannot ignore the absence or existence of a criminal record of the nature of the offense, but also of the detainee when deciding on conditional release, since his attitude is particularly important past the requirements of criminal law. The success of the first offense contributes as an incentive for other criminal offenses (Ibidem).

Our opinion is that the nature and manner of committing the offense, whether or not it was committed by violence, must be relevant when analyzing the person by the conditional liberation commission and/or when determining the execution regime in the sense that it is strict enforcement of the execution regimes according to Law no 254/2013 on the execution of the punishments and the deprivation of liberty ordered by the judiciary bodies in the course of the criminal trial shall also be made according to the deed committed.

\section{Conclusions}

Regarding criminals such as those presented above, relapse is just a matter of time. In their case, we did not wonder if they would commit crimes, but when. We all have to ask this question, even the state authorities, and the bodies empowered to find solutions to the existing precedents and to the many cases that do not cease to surprise us. The Romanian Criminal Legislator itself, as legal provisions, to prevent such acts.

The proposed de lege ferenda aims at ensuring the scope of punishment, namely to prevent the commission of new offenses and, on the other hand, to respond to the present needs of the community so as to avoid creating a framework legal framework by which dangerous perpetrators can relapse.

Education for the prevention and fight against crime, including when it comes to recidivists, also includes awareness among all generations, especially young people, of the particularly important role of our state's struggle for social defense against crime, formation and modeling at all ages of life, justice, understanding of the objectives, content and purpose of the struggle to prevent and combat crime, the special awareness of each individual's right to life, "the special formation of a militant attitude on the need for the closest cooperation of the political forces of everybody interested in disarmament" (see Chitoran and Năstase 1980, 323-328).

One last argument that the present paper proposes to analyze is the one regarding the functions and purpose of the punishment, the pylon of criminal law, to which the person requesting 
conditional liberation. The jurisprudence retains the amount of punishment as generally required to be executed in full in order to perform all the functions of punishment (see Decision no 406/08.06.2011 delivered by the Prahova Law Court). And we add that, especially in the case of offenders committing crimes, they are forced by violence and means that attract the abhorrence of those around them that they do not benefit from the provisions of this institution.

Regarding the necessity of the institution of legal liability, this is a consequence of the violation of the norms of law, but also an important way to achieve the rule of law; it is regulated as a fundamental institution, inherent in any state, sure that alongside the institution of crime and that of punishment. The existence of criminal liability implies also enforcement of the conviction, which, in the case of certain offenders and certain offenses, will last until the punishment imposed by the court (Bulai 1997, 315-316).

It remains to be noticed, in the years to come, how the criminal legislator will "react" to the cases in practice and to what extent will he manage to solve this desideratum.

\section{References}

Antoniu, G. 1998. "Contributions to the study of punishment” in R.D.P. no 2.

Bălăşescu, M. 2015. Conditional liberation in the regulation of the New Criminal Code and Law no 254/2013. Bucharest: Hamangiu Publishing House.

Boiangiu M. in "Dilema” no 346.

Bulai, C. 1997. Criminal Law Handbook, General Part. Bucharest: All Educaţional Publishing House.

Butoi, I.T., and Butoi, T. 2004. Judicial psychology. Bucharest: Fundaţia România de Mâine.

C.E.D.O. 1991. Decision Observ and Guardian v. Great Britain, dated 26.11.1991, 59, apud http://www.echr.coe.int.

Chitoran, D., and Năstase, A. "Education for disarmament - content and forms." In "Review of the Romanian National Commission for UNESCO" no 4/1980.

Decision no 406/08.06.2011 delivered by the Prahova Law Court.

Gheorghe F. 2005. Criminality Prevention. Theory and Practice. Bucharest: Oscar Print Publishing House.

Antonescu, D. 2017. “Anchetele comisarului Antonescu (Commissioner Antonescu's inquiries).” Accessed February 23, 2019 https://www.facebook.com/AncheteleComisaruluiAntonescu/videos/1329115560549609/

Pascu, I., and Uzlău, A.S. 2013. Criminal law. General Part. $3^{\text {rd }}$ ed. Bucharest: Hamangiu Publishing House.

Romanian Criminal Code.

Romanian Criminal Procedure Code.

Tanoviceanu, I. 1927. Treaty of Law and Criminal Procedure. $2^{\text {nd }}$ ed. vol. III. Bucharest: Tiparul Curierul Judiciar.

The Criminal Code, The Criminal Procedure Code. 2017. Carefully edited and annotated by Tudorel Toader. Bucharest: Hamangiu Publishing House.

Udroiu, M. 2014. Criminal law files. General part, according to the New Criminal Code. Bucharest: C.H. Beck Publishing House. 